\title{
Colour Changes in Broiler Chicken Breast Muscles Fed on Diets Containing Nigella (Nigella sativa), Ginger (Zingiber Officinale) and Garlic (Allium Sativum) with Different Concentrations
}

\author{
Aljabeili, H. S. \\ Food Science \&Human Nutrition Department, College of Agriculture and Veterinary Medicine, Qassim University, Saudi Arabia
}

\begin{abstract}
A total of 30 broiler chickens fed on a ration containing Nigella (Nigella sativa), Ginger (Zingiber officinale) and Garlic (Allium sativum) in concentrations of 0 (control), $1 \%$, $2 \%$ and $3 \%$ for 45 days. The meat cuts were evaluated for the effects of the rations on colour changes of the muscles stored for one week at refrigeration temperature $\left(4^{\circ} \mathrm{C}\right)$.The colour of the samples were measured day 0 (first day) and after one week of the storage. The results showed that at first day of treatment no significant differences were found in the redness values between control sample and samples treated with Ginger in concentration of 3\% and Nigella in concentration of $1 \%$. After one week of the storage the highest value for $L^{*}$ (lightness) was observed in control sample (62.5) followed by sample treated with Ginger in concentration of $1 \%$ (54.3) and sample treated with Nigella (\%52.5) in the concentration of 3\%. It was also observed that significant differences in redness for the control sample, sample fed on $2 \%$ of Ginger, sample fed on $2 \%$ of Garlic and sample fed on $3 \%$ of Nigella.
\end{abstract}

Keywords: Broiler chicken, Diets, Nigella, Ginger, Garlic

\section{Introduction}

Colour of animals normally influenced by some factors such as animal species, breeding, genotype, gender, age and diet which plays a critical role that affecting the colour of the produced meat (Mohamed et al., 2008, Jamilah et al., 2009).Numerous studies specified that the main compound with coloring function in meat are the carotenoids (Blanch \& Hernandez, 2000, Breithaupt, 2007).

Carotenoids which have antioxidant effect are essential for the immune system and cannot be synthesized by poultry. These compounds from the diet (Jung et al. 2012). Xiong (2000, Lund et al., 2008) reported that during meat storage, oxidative modificationof amino acid could result in physical and chemical changes, includingchanges to conformational stability, solubility, and nutritional quality. Several studies were conducted with objective of investigating changes in colour of chicken meat as affected by diets supplementations with various functional food materials (Anjum et al., 2013, Menconi et al., 2014, Zheng et al., 2014, Goliomytis et al., 2015, Al-Hijazeen et al., 2016a, Al-Hijazeen et al., 2016b, Garcia et al., 2013, Wang et al., 2017). There is a lack in research about the effects of dietary treatments combined packaging and storage condition chicken meat colour changes. Therefore, the purpose of this study wasto evaluate the effects of addition of Nigella (Nigella sativa), Ginger (Zingiber officinale) and Garlic (Allium sativum) with different concentrations to the standard diets on the colour stability and changes of broiler chicken breast meat.

\section{Material and Methods}

Broiler chickens (1200 birds) were divided into four groups, and fed a single diet throughout the experiment for 45 days. Ten birds from each group were selected randomly.
Standard mixture was based on corn, crushed soybeans which bought from General Organization for Grains, Saudi Arabia. The content and nutritional value of the standard ration mixture are shown in Table 1. Group I - control (fed with standard mixture); Group II- (fed with standard mixture supplemented with crushed Ginger in concentration of $1 \%$, $2 \%$ and 3\%; Group III- (fed with standard mixture supplemented with Garlic crushed Garlic in concentration of $1 \%, 2 \%$ and $3 \%$ and Group IV(fed with standard mixture supplemented with Garlic crushed Nigella in concentration of $1 \%, 2 \%$ and $3 \%$. The birds were slaughtered, defeathered, eviscerated and breast muscles were obtained and aerobically packed in polyethylene vinyl acetate (PVA) plastic bags for one week. Colour of the control and diet treated breasts has been determined using CIE and CIE Lab system. Dominant wavelength $\lambda(\mathrm{nm})$ and colour purity $\check{C}$ (\%) has been determined using chromaticity diagram. Colour values (L*, lightness; $\mathrm{a}^{*}$, redness andb*, yellowness)have been calculated according to CIE Lab system and the averageof each value calculated.

Table 1: Contents and percent of standard mixture used for control diet

\begin{tabular}{|c|c|c|}
\hline S. No. & Name of the item & Concentration \\
\hline 1 & protein & $20.5 \%$ \\
\hline 2 & fat & $6 \%$ \\
\hline 3 & crude fibre & $3.3 \%$ \\
\hline 4 & ash & $5.5 \%$ \\
\hline 5 & calcium & $0.9 \%$ \\
\hline 6 & salt & $0.35 \%$ \\
\hline 7 & phosphorus & $0.65 \%$ \\
\hline 8 & vitamin A & $10 \mathrm{mg} / \mathrm{g}$ \\
\hline 9 & vitamin D & $3 \mathrm{mg} / \mathrm{g}$ \\
\hline 10 & vitamin K & $25 \mathrm{mg} / \mathrm{g}$ \\
\hline
\end{tabular}




\section{International Journal of Science and Research (IJSR) ISSN (Online): 2319-7064}

Index Copernicus Value (2015): 78.96 | Impact Factor (2015): 6.391

\section{Statistical Analysis}

Minitab Statistical Software (Minitab Inc., PA, USA) package 17 was used for data analysis. Two-way analysis of variance (ANOVA) to evaluate diets treatments and storage condition on colour changes of the samples. Differences between samples were considered significant when $P<0.05$.

\section{Results and Discussion}

Table 2: Values of colour of different treated chicken cuts stored at $4^{\circ} \mathrm{C}$ for 7 days

\begin{tabular}{|c|c|c|c|c|}
\hline & $\begin{array}{c}\text { Dietary } \\
\text { treatment }\end{array}$ & $\begin{array}{c}L^{*} \\
\text { (lightness) }\end{array}$ & $\begin{array}{c}a^{*} \\
\text { (redness) }\end{array}$ & $\begin{array}{c}b^{*} \\
\text { (yellowness) }\end{array}$ \\
\hline $47.2 \pm 0.2$ & Control & $47.2 \pm 0.2$ & $10.4 \pm 0.1$ & $13.41 \pm 0.1$ \\
\hline \multirow{9}{*}{$\begin{array}{c}\text { First } \\
\text { day of } \\
\text { storage }\end{array}$} & Ginger $1 \%$ & $44.2 \pm 0.1$ & $4.2 \pm 0.2$ & $13.21 \pm 0.3$ \\
\hline & Ginger $2 \%$ & $39.7 \pm 0.3$ & $7.0 \pm 0.3$ & $13.29 \pm 0.2$ \\
\hline & Ginger 3\% & $48.3 \pm 0.1$ & $10.2 \pm 0.2$ & $13.32 \pm 0.2$ \\
\hline & Garlic $1 \%$ & $45.8 \pm 0.2$ & $7.7 \pm 0.2$ & $9.65 \pm 0.3$ \\
\hline & Garlic $2 \%$ & $42.6 \pm 0.3$ & $5.3 \pm 0.1$ & $9.60 \pm 0.1$ \\
\hline & Garlic 3\% & $51.8 \pm 0.1$ & $8.2 \pm 0.2$ & $9.59 \pm 0.3$ \\
\hline & Nigella $1 \%$ & $48.7 \pm 0.2$ & $10.1 \pm 0.1$ & $12.61 \pm 0.3$ \\
\hline & Nigella $2 \%$ & $54.7 \pm 0.4$ & $5.4 \pm 0.3$ & $12.27 \pm 0.1$ \\
\hline & Nigella 3\% & $48.0 \pm 0.1$ & $9.5 \pm 0.1$ & $13.26 \pm 0.3$ \\
\hline \multirow{10}{*}{$\begin{array}{c}\text { One } \\
\text { week } \\
\text { of } \\
\text { storage }\end{array}$} & Control & $62.5 \pm 0.1$ & $6.4 \pm 0.2$ & $15.55 \pm 0.3$ \\
\hline & Ginger $1 \%$ & $58.5 \pm 0.1$ & $3.6 \pm 0.1$ & $18.35 \pm 0.2$ \\
\hline & Ginger $2 \%$ & $48.4 \pm 0.2$ & $6.1 \pm 0.2$ & $16.22 \pm 0.1$ \\
\hline & Ginger 3\% & $46.5 \pm 0.1$ & $3.1 \pm 0.1$ & $16.65 \pm 0.2$ \\
\hline & Garlic $1 \%$ & $43.6 \pm 0.3$ & $5.4 \pm 0.2$ & $17.4 \pm 0.2$ \\
\hline & Garlic $2 \%$ & $51.1 \pm 0.1$ & $6.2 \pm 0.1$ & $15.22 \pm 0.3$ \\
\hline & Garlic 3\% & $46.8 \pm 0.2$ & $4.8 \pm 0.3$ & $12.45 \pm 0.1$ \\
\hline & Nigella $1 \%$ & $45.9 \pm 0.2$ & $3.4 \pm 0.1$ & $14.51 \pm 0.1$ \\
\hline & Nigella $2 \%$ & $54.3 \pm 0.3$ & $5.7 \pm 0.1$ & $13.82 \pm 0.2$ \\
\hline & Nigella 3\% & $52.5 \pm 0.1$ & $6.0 \pm 0.3$ & $12.31 \pm 0.1$ \\
\hline
\end{tabular}

The colour values of the chicken breast muscles $\mathrm{L}^{*}, \mathrm{a}^{*}, \mathrm{~b}^{*}$ are presented in Tables 2, figure 1 and 2, respectively. It is clear observed that the feeding system use influenced colour properties of the samples significantly $(\mathrm{P}<0.05)$. The values of colour in control sample at the first day of storage were 47.2, 10.4 and 13.41 for $\mathrm{L}^{*}, \mathrm{a}^{*}, \mathrm{~b}^{*}$, respectively. These values increased to 62.5 for $\mathrm{L}^{*}$ (lightness) and 15.55 for $\mathrm{b}^{*}$ (yellowness) but decreased to 6.4 for $\mathrm{a}^{*}$ (redness) after one week of the storage. The treated samples showed the same trend at first day but generally comparing to the control $\mathrm{L}^{*}$ values ranged from $39.7-54.7$, a* values ranged $4.2-10.2$ and $b^{*}$ values ranged from $9.59-13.32$. The lowest value for redness was observed in the sample treated with $1 \%$ of Ginger followed by sample treated with and $2 \%$ of Nigella. However, no significant difference $(\mathrm{p}<0.01)$ were found in the redness values between control sample and samples treated with Ginger in concentration of $3 \%$ and Nigella in concentration of $1 \%$. Karaoğlu et al. (2006) investigated broiler carcasses during post-mortem fed with dietary probiotics and slaughtered at different ages and found that $\mathrm{L}^{*}$ values were lower for slaughter at 42 days of age $(\mathrm{p}<0.01)$. It can be influenced by increasing $\mathrm{a}^{*}$ and $\mathrm{b}^{*}$ values. Because, when $a^{*}$ and $b^{*}$ values increased $L^{*}$ value declined and the colour gradually darkened.This is might be due to the stability of reduction of red pigment of the samples. Moreover, the same trend was observed in the treated samples after one week of the storage. The highest value for $\mathrm{L}^{*}$ (lightness) was observed in control sample (62.5) followed by sample treated with Ginger in concentration of $1 \%$ (54.3) and sample treated with Nigella $(\% 52.5)$ in the concentation of $3 \%$. It was noticed from sensory attributes viewpoint, that the best colour of broiler chicken was obtained in chicken meat fed on the ration contained Nigella in the concentration of $1-3 \%$, followed by values of $7.4-7.9$ which obtained in chicken meat fed on the ration contained Garlic in the concentration of $1-3 \%$, followed by values of $6.9-7.3$ which obtained in chicken meat fed on the ration contained Ginger in the concentration of $1-3 \%$ and the control 6.4 fed on the ration without treatment (Aljabeili et al. (2016). However, the stability of the meat colour during the period of the storage could be due to the antioxidant effects of the medicinal plants that added to the ration of the chicken which considered as natural antioxidants (AbdElgadir, 2016). At the end of the storage it was noticed that no significant differences in redness for the control sample, sample fed on $2 \%$ of Ginger, sample fed on $2 \%$ of Garlic and sample fed on $3 \%$ of Nigella. This is might be due to the stability of meat pigment of the samples when treated with these concentration.

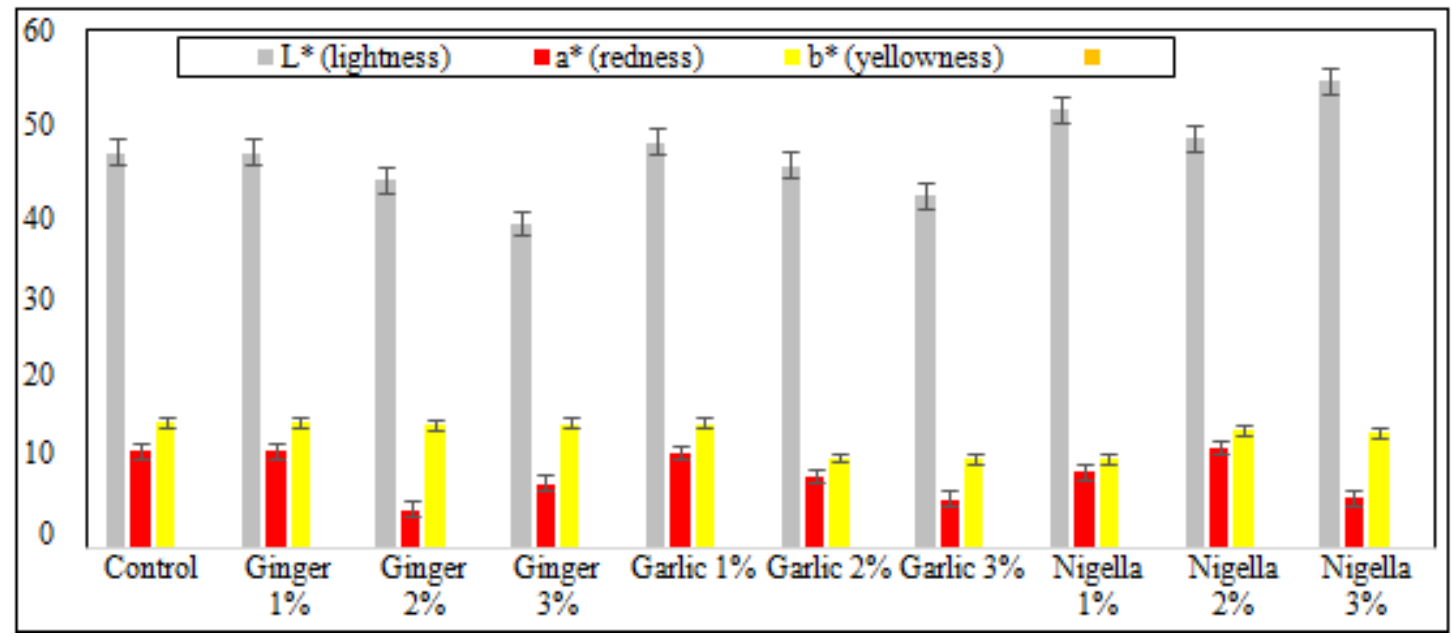

Figure 1: Colour values of different treated chicken cuts stored at $4^{\circ} \mathrm{C}$ on first day

Volume 6 Issue 7, July 2017 www.ijsr.net

Licensed Under Creative Commons Attribution CC BY 
International Journal of Science and Research (IJSR)

ISSN (Online): 2319-7064

Index Copernicus Value (2015): 78.96 | Impact Factor (2015): 6.391

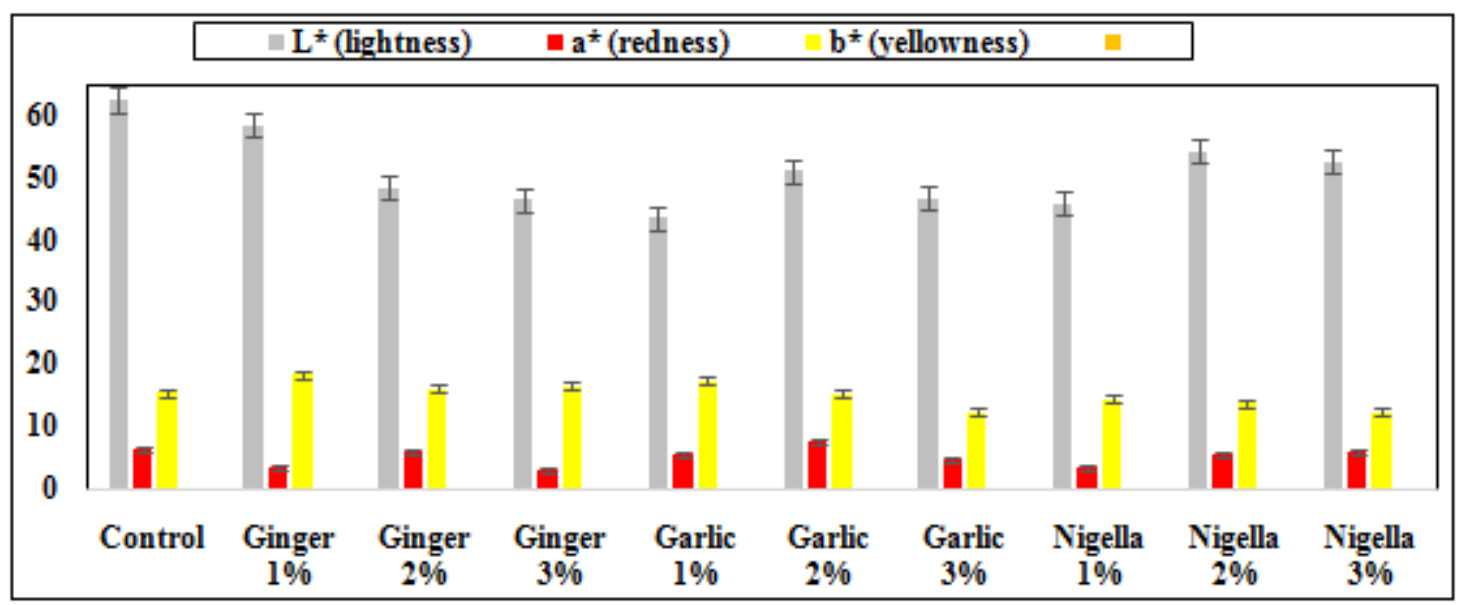

Figure 2: Colour values of different treated chicken cuts stored at $4^{\circ} \mathrm{C}$ one week

\section{Conclusion}

It can be concluded that, broiler chickens fed on a ration containing Nigella (Nigella sativa), Ginger (Zingiber officinale) and Garlic (Allium sativum) in the mentioned concentrations stored at $4^{\circ} \mathrm{C}$ for 7 days gave different colour values. For better keeping quality of broiler breast meat, diets containing $2 \%$ of Ginger or $2 \%$ or $3 \%$ of Nigella are highly recommended. More research might be suggested to investigate the effects of combinations of these medicinal plants in the diets of the chicken.

\section{References}

[1] Al-Hijazeen M, Lee EJ, Mendonca A, Ahn DU. $2016 \mathrm{a}$. Effect of Oregano Essential Oil (Origanum vulgare subsp. hirtum) on the Storage Stability and Quality Parameters of Ground Chicken Breast Meat. Gieseg SP, ed. Antioxidants.

2016;5(2):18. doi:10.3390/antiox5020018.

[2] Al-Hijazeen, M, Lee EJ, Mendonca A, Ahn DU. 2016 b. Effects of Tannic Acid on Lipid and Protein Oxidation, Color, and Volatiles of Raw and Cooked Chicken Breast Meat during Storage. Arráez-Román D, ed. Antioxidants.

2016;5(2):19. doi:10.3390/antiox5020019.

[3] Aljabeili, M. Abd Elgadir, Abdulaziz A. ALsuhaim and A. Al Homidan. 2016. Sensory Evaluation of Various Chicken Cuts Fed on Rations Containing Ginger (Zingiber Officinale), Garlic (Allium Sativum) and Nigella (Nigella Sativa) with Different Concentrations. International Journal of Advanced Research 4(10), 1- 4.

[4] Anjum FM, Haider MF, Khan MI, Sohaib M, Arshad MS. Impact of extruded flaxseed meal supplemented diet on growth performance, oxidative stability and quality of broiler meat and meat products. Lipids in Health and Disease. 2013; 12:13. doi:10.1186/1476511X-12-13.

[5] Blanch A, Hernandez JM. Red carotenoids for optimal yolk pigmentation. Feed Mix 2000; 8:9-12.

[6] Breithaupt DE. Modern application of xanthophylls in animal feeding. A review. Trends in Food Science and Technology 2007; 18:501-506.

[7] Garcia, AFQM, Murakami AE, Duarte CR do A, Rojas ICO, Picoli KP, Puzotti MM. Use of Vitamin $\mathrm{D}_{3}$ and Its Metabolites in Broiler Chicken Feed on Performance,
Bone Parameters and Meat Quality. Asian-Australasian Journal of Animal Sciences. 2013;26(3):408-415. doi:10.5713/ajas.2012.12455.

[8] Goliomytis M, Kartsonas N, Charismiadou MA, Symeon GK, Simitzis PE, Deligeorgis SG. The Influence of Naringin or Hesperidin Dietary Supplementation on Broiler Meat Quality and Oxidative Stability. Han JY, ed. PLoS ONE. 2015;10(10):e0141652.

doi:10.1371/journal.pone.0141652.

[9] Jamilah, B., Mohamed, A., Abbas, K.A. and Abdul Rahman, R. and Karim, R. 2009. A review on the effect of animal diets and presence of selected natural antioxidants on lipid oxidation of meat. Journal of Food, Agriculture \& Environment Vol.7 (2): 76 - 81.

[10]Jung EK, Clark RM, Park Y, Lee J, Fernandez ML. Lutein decreases oxidative stress and inflammation in liver and eyes of guinea pigs fed a hypercholesterolemic diet. Nutrition Research Practice 2012; 6:113-119.

[11] Karaoğlu, M., Aksu1, M. İ., Esenbuga, N., Macit, M. and Durdağ, H. 2006. pH and Colour Characteristics of Carcasses of Broilers Fed with Dietary Probiotics and Slaughtered at Different Ages. Asian-Aust. J. Anim. Sci., 19 (4): 605-610.

[12] Menconi A, Kuttappan VA, Hernandez-Velasco X, et al. Evaluation of a commercially available organic acid product on body weight loss, carcass yield, and meat quality during preslaughter feed withdrawal in broiler chickens: A poultry welfare and economic perspective. Poultry Science. 2014; 93(2):448-455. doi:10.3382/ps.2013-03444.

[13] Mohamed, A., Jamilah, B., Abbas, K.A. and Abdul Rahman, R. 2008. A review on some factors affecting colour of fresh beef cuts. Journal of Food, Agriculture \& Environment, 6 (3\&4): 181 - 186.

[14] Wang S, Zhang L, Li J, Cong J, Gao F, Zhou G. Effects of dietary marigold extract supplementation on growth performance, pigmentation, antioxidant capacity and meat quality in broiler chickens. Asian-Australasian Journal of Animal Sciences. 2017; 30(1):71-77. doi:10.5713/ajas.16.0075.

[15]Xiong, Y. L. 2000. Protein oxidation and implication for muscle food quality. Pages $85-112$ in Antioxidants in Muscle Foods: Nutritional Strategies to Improve Quality. E. A. Decker, C. Faustman, and C. J. LopezBote, ed. John Wiley and Sons, New York, NY. 


\section{International Journal of Science and Research (IJSR) \\ ISSN (Online): 2319-7064}

Index Copernicus Value (2015): 78.96 | Impact Factor (2015): 6.391

[16]Zheng A, Luo J, Meng K, et al. Proteome changes underpin improved meat quality and yield of chickens (Gallus gallus) fed the probiotic Enterococcus faecium. BMC Genomics. 2014; 15(1):1167. Doi:10.1186/1471-2164-15-1167.

Volume 6 Issue 7, July 2017 www.ijsr.net 